\title{
EFFECT OF PREHARVEST FOLIAR SPRAY WITH GIBBERELLIC ACID AND CALCIUM ON YIELD AND QUALITY OF ON -TREE STORED FRUITS OF NAVEL ORANGE. \\ Barakat, M.R. ${ }^{1}$; A. El-Ezaby'; S.E. Salem ${ }^{2}$ and A.M. El-Azaze ${ }^{2}$ \\ ${ }_{1}^{1}$ Pomology Department, Faculty of Agriculture, Cairo University. \\ 2 Horticulture Research Institute. Agriculture Research Center, Giza
}

\begin{abstract}
This experiment was carried out during two successive seasons (2002-2003 and 2003-2004) on Washington navel orange trees 30 year old grafted on sour orange grown in a private orchard in Elkaliobia Governorate to explore the possible effects of foliar application of gibberellic acid at 10,15,20ppm and calcium chloride at $1 \%$ and $2 \%$ on the quality of on-tree-stored fruits of Washington navel orange. Treatments were applied at fruit color break as whole tree sprays .Fruits were harvested at four dates January, February, March, and April. Yield and fruit quality parameters were recorded.

Gibberellic acid at 20ppm significantly decreased the reduction in fruit weight, fruit drop and increased juice weight percentage, juice acidity, ascorbic acid Nevertheless $\mathrm{GA}_{3}$ at all the tested concentrations minimized the peel thickness in the last harvesting date and decreased juice T.S.S

Calcium chloride at $2 \%$ caused significant increases in fruit weight, juice weight percentage, juice acidity, ascorbic acid and insignificant increase in peel thickness while it significantly decreased number of fruit dropped and juice T.S.S
\end{abstract}

\section{INTRODUCTION}

Navel orange is considered as the most popular citrus variety for both local consumption and export thus there is an economical importance for prolonging the period of marketing which may be achieved by storing fruit on tree or tree storage (Mehana et al., 1987) .On the other hand keeping Navel fruits on tree after maturation reduce its marketability due to the development of certain rind disorders. Moreover, long harvest season may result in reduction in the total yield by increasing fruit drop percentage (El-Otmani, 1991).

Gibberellic acid is commonly applied to citrus intended for the fresh -fruit market because such applications improve peel quality, delay rind coloration and delay the onset of senescence related to peel disorders thus extending the harvest season when applied as a preharvest spray '( $\mathrm{El}$ Otmani, 1991 and Fidelibus, et al., 2002).

Gibberellic acid is used by citrus growers not only to increase rind firmness externally, but also internally moreover it retains the fruit round shape and reduces fruit drop in Navel orange(Harty et al., 2004) .

Calcium plays an important role in maintaining cell wall structure and delay cell wall breakdown and fruit softening (Poovaiah, 1988 and Ferguson, 1988) . On the other hand, this application depressed respiration in some fruits and salts prevent ethephon- induced-abscission in mandarins (Hsiung and Iwahori , 1984). Moreover, calcium reduced number of dropped fruits this may be attributed to the effect of calcium in inhibiting ethylene biosynthesis (Poovaiah and Leopoid 1973). 


\section{Barakat, M.R. et al}

The objective of this investigation was to find out the best concentration of calcium chloride, gibberellic acid for prolonging the period of the on- tree storage of Navel orange and investigating it's effect on the physical and chemical properties of the on- tree storage fruit .

\section{MATERIALS AND METHODS}

The present investigation was carried out during the two successive seasons (2002-2003) and (2003-2004)on Washington Navel orange fruits (Citrus sinensis (L)osbeck) .The trees were 30 years old grafted on sour orange grown in a private orchard in Kafr Shokr at El Kaliobia governorate .

Thirty six trees uniform in growth were selected in a complete randomized design of about similar vigor and yield. The trees were divided into 6 groups. Each group contained 6 random trees. The date at which fruit color break occurred was determined for each season. Each group received one of the following treatments: (no treatment) control, $\mathrm{GA}_{3}$ at concentrations of 10 , $15,20 \mathrm{ppm}$ and calcium chloride at concentrations of $1 \%, 2 \%$.

Fruits were stored on tree till April .Fruit samples were harvested from each 6 replications by collecting 30 fruits from all sides of each tree to study the following parameters

\section{Physical characters:}

Fruit weight, yield /tree, axial and equatorial dimensions as well as percentage of juice contents

Chemical characters:

1- Total soluble solids percentage (TSS\%) using hand refractometer(AOAC, 1985)

2- Titatratable acidity: as citric acid grams per $100 \mathrm{ml}$ juice

3- Ascorbic acid (vitamin C): By using 2,6-dichlorophenol indophenol dye and $3 \%$ oxalic acid substrate as milligrams per 100 milliliter.

\section{Statistical analysis:}

The complete randomized block design was adopted for the experiment .The statistical analysis of the present data was carried out according to Snedecor and Chocran (1972).Averages were compared using the new L.S.D. values at $5 \%$ level. Percentages were transformed by the equation prior to the statistical analysis and thereafter percentages were presented with statistical letters.

\section{RESULTS AND DISCUSSION}

\section{Physical properties \\ 1- Fruit weight}

Data presented in Table (1) pointed that fruit weight increased gradually up to February. then decreased significantly at the late harvesting dates. The lowest values recorded were those for fruit harvested at April $15^{\text {th }}$ in both seasons of the study .

El-Otmani et al., (1991) and Fidelibus et al., (2002) obtained similar results and referred weight gain to natural increase in dimension and weight reduction to water loss. 
Concerning the specific effect of $\mathrm{GA}_{3}$ application, data obtained for both seasons (Table 1) show in general that there is no significant effect due $\mathrm{GA}_{3}$ application at 10 or $15 \mathrm{ppm}$ on fruit weight, as the recorded values followed the same trend as control during the first three harvesting dates. These results are in agreement with those of El-Otmani et al. 1991. Yet, GA 3 treatment at $20 \mathrm{ppm}$ concentration significantly decreased the sharp reduction in fruit weight during the late harvesting date in April $15^{\text {th }}$ compared with control. This may be attributed to the fact that $\mathrm{GA}_{3}$ applications reduce water loss (Fucik, 1982).

Regarding the specific effect of calcium sprays the obtained data in (Table 1) show that calcium concentration at $2 \%$ caused significant increases in fruit weight, as it reduced the decline in the fruit weight during the on-tree storage period when compared with control (Salem,1991). This may be due to the role of calcium in maintaining the cell wall structure in the fruits by interacting with the pectic acid in cell walls as mentioned by Poovaiah (1988).

\section{2-Fruit dimensions}

It is evident from (Tables 2 and 3 ) that the equatorial and axial dimensions of fruit increased gradually till March, then it decreased during April (Mehana et al. 1987)

Concerning the effect of $\mathrm{GA}_{3}$ or $\mathrm{CaCl}_{2}$ both treatments at all implemented concentrations had no significant effect on the change of fruit dimensions during both seasons.

\section{3-Rind thickness}

Data illustrated in (Table 4) As a general trend, significant reduction in peel thickness was recorded during the last two harvesting dates of March $15^{\text {th }}$ and April $15^{\text {th }}$ (Table 4). This reduction may be attributed to entering of the fruit in the over ripening stage at that late harvesting date and thus peel senescence occured in which solublization of pectin took place ( El-Otmani et al., 1991) .

Concerning the specific effect of treatments, the obtained data disclosed that $\mathrm{GA}_{3}$ relatively reduced decline of the peel thickness insignificantly when compared with control for the last harvesting date in April $15^{\text {th }}$ for both seasons. Such results are in general agreement with El-Otmani et al., (1991) and El Zeftawi, (1983) who pointed out that $\mathrm{GA}_{3}$ delays rind senescence.

As for calcium spray effect, the data showed $\mathrm{Cacl}_{2}$ treatment at $2 \%$ caused slight increases in the peel thickness when compared with control treatment.

\section{4-Juice percentage}

The obtained data in Table (5) showed that juice percentage decreased significantly at April, for both seasons. Such result was also recorded by Almeida et al.,(2004).

Concerning the specific effect of $\mathrm{GA}_{3}$ treatment, statistical analysis disclosed that fruit of trees treated with GA3 at $20 \mathrm{ppm}$ significantly contained higher juice weight content than those of the untreated ones. However these differences were not significant with treatments of GA3 at 10 and15 ppm . 
Barakat, M.R. et al

T1-2

2098 
J. Agric. Sci. Mansoura Univ., 32 (3), March, 2007

t3-4 
Dealing with, calcium treatment showed in( Table 5) illustrated that $\mathrm{CaCl}_{2}$ significantly increased the juice weight percentage at all harvesting dates when compared with control. The highest value was recorded with $\mathrm{CaCl}_{2}$ at $2 \%$ when fruits were harvested at March $15^{\text {th }}$. While, the lowest values were recorded for control when it was harvested at April for both seasons. Similar trend was mentioned by El-Shafey,(2001) on Navel orange and Kotsias,(2004) on sweet orange.

\section{5- Yield/tree}

Concerning the effect of harvesting date, it can be mentioned that yield expressed as number of fruits per tree decreased gradually with time (Table 6 ). This is attributed to the fruit drop during the storage period .Moreover, the last harvesting date showed the greatest number of dropped fruit for both seasons of the study.

Concerning the effect of $\mathrm{GA}_{3}$ it could be noticed that its applications at 15 or20 ppm significantly reduced the number of fruit drop when compared with control. A parallel trend was also achieved by calcium at $2 \%$ by reducing significantly the number of fruit dropped was markedly lower than that recorded for control treatment .

Chemical properties

\section{1-Total acidity}

Concerning specific effect of harvesting date on juice acidity, data in Table (7) show gradual insignificant reduction in fruit juice acidity up to the end of the storage period where such reduction was highly significant at the two last harvesting dates. This could be due to the increase in respiration rate of the fruit and /or as a result consumption of fruit organic acid (Abd-El-Haffz, 1999).

With regard to the specific effect of $\mathrm{GA}_{3}$, data in Tables (7) show that treatment by $\mathrm{GA}_{3}$ increased juice acidity. The increment was more pronounced with GA3 at $20 \mathrm{ppm}$. This result is in harmony with those mentioned by Abd-Elhaffez, (1999). He pointed out that $\mathrm{GA}_{3}$ generally increases the juice acidity. On the other hand, El-Otmani et al. (1991) pointed out that $\mathrm{GA}_{3}$ has no effect on internal fruit quality.

regarding to the specific effect of calcium chloride, it is clear that calcium at $2 \%$ increased significantly juice acidity for all harvesting dates. This may be due to the role of calcium in depressing the respiration rate of fruit. This result is in accord with Poovaiah, (1988). He reported that calcium treatment depressed respiration rate. Also our results parallel those obtained by Tripathi and Bhorgrave 1993 on apple. It could be noticed that both $\mathrm{GA}_{3}$ and $\mathrm{CaCl}_{2}$, reduced significantly the decrease in fruit acidity for the untreated fruit during storage period.

The highest value for fruit juice acidity was recorded for $\mathrm{GA}_{3}$ at $20 \mathrm{ppm}$ and calcium at $2 \%$ at the 3rd harvesting date while the lowest recorded value was for untreated fruit harvested at April15 ${ }^{\text {th }}$. 
J. Agric. Sci. Mansoura Univ., 32 (3), March, 2007

T5-6-7 


\section{Barakat, M.R. et al}

2-T.S.S

Concerning the effect of harvesting date, the data shown in Table (8) indicate that, fruit juice T.S.S. increased with advancing harvest date and being highly significant for the last harvesting date as the highest T.S.S value was recorded at April $15^{\text {th }}$ in both seasons of the study.

The above mentioned results are in harmony with those obtained by Echerverria and Valich, (1989), El-Otmani et al.,(1989) and Mehana, (1987). They pointed out that the increase in T.S.S of on-tree storage fruit is attributed to the conversion of organic acid to glycoltic intermediates and sugar or attributed to water loss from fruit.

Concerning the effect of $\mathrm{GA}_{3}$ the data illustrated in Table ( 8 ) revealed that in general, that fruits sprayed by $\mathrm{GA}_{3}$ concentrations showed significant decrease in juice T.S.S when compared with control .

Moreover, the obtained data appeared that $\mathrm{GA}_{3}$ at 15 or $20 \mathrm{ppm}$ shows significant reduction in juice T.S.S when compared with $\mathrm{GA}_{3}$ at $10 \mathrm{ppm}$, for both seasons. This result is in line with those reported by Harty, (2004) and Abd- El-Hafeez, (1991). On other the hand, Fidelibus, et al., (2002) reported that applying $\mathrm{GA}_{3}$ decrease T.S.S of Hamlin and Valencia oranges.

Concerning the specific effect of $\mathrm{CaCl}_{2}$ data in Table (8) showed that calcium treatments decreased significantly juice T.S.S of on tree storage fruit, for both seasons. However, such difference did not attain the level of significant when $\mathrm{CaCl}_{2}$ was used at $1 \%$

3-Ascorbic acid

As regard to the effect of harvesting date, it could be noticed that ascorbic acid values decrease gradually as the harvest season advance after Feb. and the lowest recorded values were obtained when fruits were harvested at April $15^{\text {th }}$.

All $\mathrm{GA}_{3}$ concentrationstended to produce insignificant increase in fruit ascorbic acid content except for $\mathrm{GA}_{3}$ at 20ppm where ascorbic acid content wassignificantly higher than the control .

The above mentioned results are in accordance with those reported by Zhang, (1987) and Abd El-Hafeez, (1991). They pointed out $\mathrm{GA}_{3}$ sprays increase fruit vitamin $C$.

As for the effect of calcium results in hand show that treatment with $\mathrm{CaCl}_{2}$ for both concentrations have cause a significant increase in juice ascorbic acid during storage period. This could be attributed to effect of calcium in depressing the rate of respiration of fruit which affects ascorbic acid degradation (Burdurlu et al., 2006).

Overall, it could be concluded that both $\mathrm{GA}_{3}$ and Calcium sprays have reflected a positive unique impact on navel orange on-tree storage as expressed by reducing decline in fruit weight, peel thickness and minimizing fruit drop, whereas, they tended to increase fruit juice content, juice acidity and vitamin content, while TSS was reduced. 


\section{REFERENCES}

Abd El-Hafeez, A.A.(1999):Physiological studies on the handling and storage of Navel orange ph.D Thesis ,Fac.Agric.,Al Azhar Uni., Egypt.

Almeida,I.M.L.(2004):Application of plant growth regulators at pre-harvest for fruit development of "PERA"oranges .Brazilian archives of biology and technology Vol.47,No.4:pp.511-520

Association of Official Agricultural Chemists (1985): Official Methods of Analysis A. O.A.C., BenjAumin Franklin Station,Washington, D.C.N.S.A.pp 440-510.

Burdurlu,H.S.;Koca.and Karadeniz,F.(2006):Degradation of vitamin C in citrus juice concentrates during storage Journal of food engineering 74(2): 211-216

Echeverria,E,and Valich,J.,(1989):Enzymes of sugar and acid metabolism in stored Valencia oranges. J.Am.Soc.Hortic.Sci.,114:445-449.

El-Otmani ,M and Coggins, C.W.,Jr.,(1991):Growth regulator effects on retention of stored citrus fruits. Sci. Hort.,45:261-272.

El-Shafey,Y.H; Abd El-Rahman ,A.M.,and El-Azaze,A.M.(2001):Effect of foliar application with calcium on yield and fruit quality of Valencia orange . Bull.Fac.Agric.,Cairo Univ.53:275-288.

El-Zeftawi B.M. and Dimsey R.T. (1983) : Evaluation of abscission chemicals in various combinations for loosening Valencia orange during regreening . J.Amer. Soc. Hort. Sci.,58(1):129-139.

Ferguson I.B. and Drobak B.K.(1988):Calcium and the regulation of plant growth and senescence. Hort.Sci., 23 (2):2312, 262-266.

Fidelibus,M.W.,Davies,F.S., and Campbell C.A. (2002):Gibberellic acid application timing affect fruit quality of processing oranges. Hort.sci.37(2):353-357

Fucik,J.E(1982): The effect of preharvest foliar spray of 2,4-D and gibbbrillic acid on the post harvest storage characteristics of "Ruby Red" grape fruit Proc.Intl.soc. Citricult. 1:221 224

Harty,A.Dooling,W. and.Little A (2004) :Producing world class navel orange in NewZeland.part2:Rind strengthening and citcling spray research orchardist $77(5): 58-61$

Hsiung.T.C and Iwahori. S.(1984):Prevention of abscission of ponkan, citrus reticulata Blanco, leaves by various calcium salts. Mernoirs of the faculty of Agriculture,Kagoskima University, 20:55-62.

Kotsias, D.(2004):Influence of Citrus auratium L.and Poncirus trifoliata(L.)Raf. rootstocks and nutrient sprays on granulation of Valencia sweet orange.European Journal of Horticultural Science ;69(6):244-249

Mehana,S.A;Elnokrashy,M.A;Salem S.E; and KoukaH.A.(1987): On -tree storage in relation to yield; fruit quality and physiological behaviour of Navel orange trees. Zagazig Jour.Agric.Res.Vol.14 (2) 17-39.

Poovaiah,B.W. and Leoplod,A.C.(1973). Inhibition of abscission by calcium. Plant Physiol., 51:848-851.

Poovvaiah, B.W.(1988):Molecular and cellular aspects of calcium action in plants. Hort. Sci.,23(2):267-270. 


\section{Barakat, M.R. et al}

Salem,A.T. and El-Khoreiby,A.M.K(1991)Effect of pre-harvest sprays of calcium chloride and storage temprature on quality and decay percentage of grapefruit.Bulletin of Faculty of Agriculture ,University of Cairo.

Snedecor, G. W. and Cochran, W.G. (1972): Statistical Methods . 6th ed, The lowa State Univ. Press . Ames. , lowa , U.S.A. , pp. 50

Tripathi,S.N.,and Bhargava ,J.N.(1993):Effect of pre-harvest treatment of fungicids and chemicals on the post-behaviour of red delicious apple in air-cooled storage .Advances in Hort.and forestry 3: 77-79 (C.F. Hort. Abst. 65:7717,1995)

Zhang,J.K.(1987):Studies on tree storage of fruits of the orange (citrus sinensis) cultivar Huazhou .Acta-Horticulturae-Sinica.14:2,103-107.

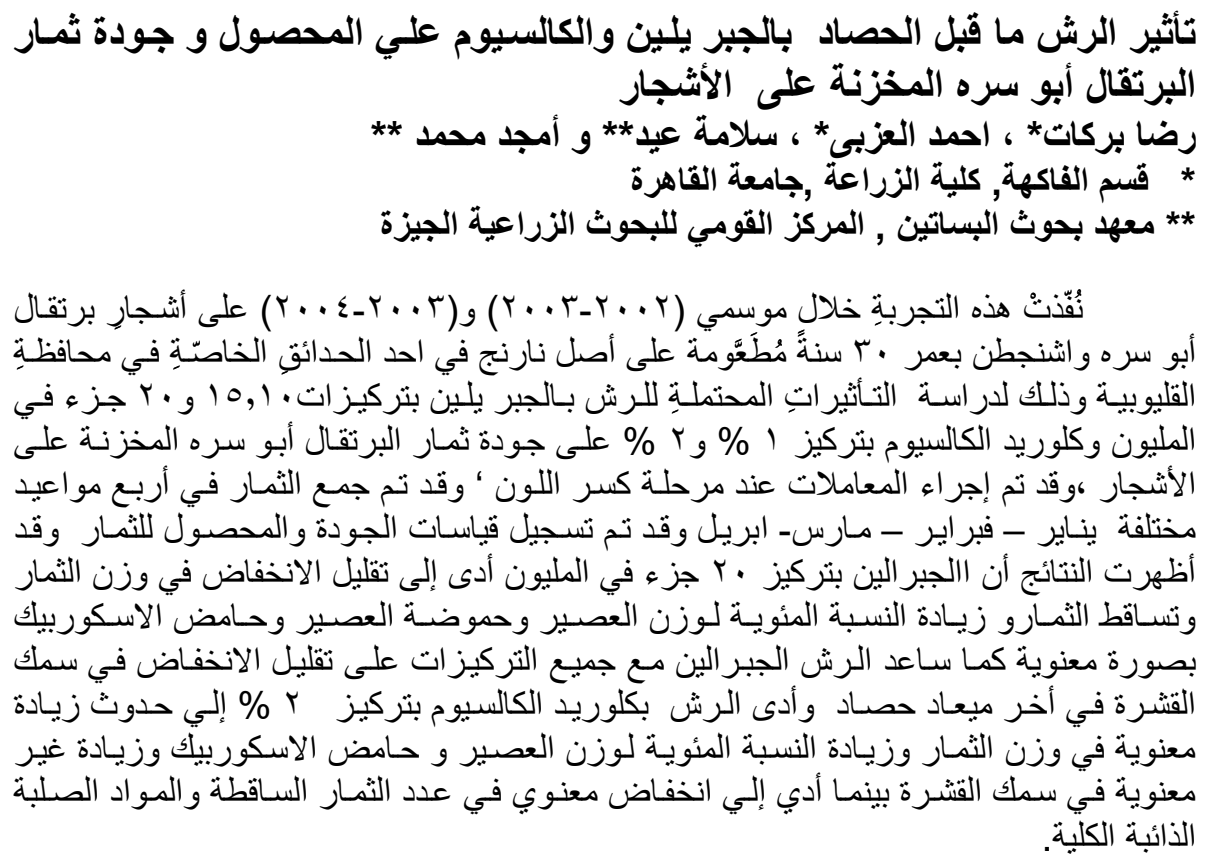

